\title{
Obezitenin kadınlarda sebep olduğu hormonal bozukluklar ve yol açtı̆̆ sorunlar
}

\author{
Solmaz Nurbanu KILIÇa
}

\section{ÖZET}

Dünya Sağlık Örgütü'ne göre obezite, sağlık için vücutta risk oluşturan anormal veya aşırı yağ birikimidir. 1980’li yıllardan bu yana dünyada her kesimi etkisi altına alan obezitenin prevelansı da hızla artmaktadır. Obezitenin oluşumunda bireylerde enerji alımının fazla olması ve fiziksel aktivitenin az olması ana etmenler olarak yer almakla birlikte; genetik yatkınlık, psikolojik ve sosyoekonomik etkenler, yaş, cinsiyet gibi durumlar da obezite geliş̧imini arttırmaktadır. Ayrıca obezite bütün yaş grupları için risk oluşturmanın yanında birçok hastalığa da yol açmaktadır. Özellikle kadınlarda daha çok görülmekle beraber, yapılan birçok çalışmada artmış adipoz dokunun vücut içerisinde değişikliklere sebep olarak polikistik over ve infertilite, gebelikle oluşan komplikasyonlar, bazı kanser türleri gibi birçok hastalığa ve soruna yol açtığı belirtilmektedir. Bu derlemede, obezitenin kadınlar üzerindeki etkileri ve sonucunda oluşan problemler üzerinde durulmaktadır.

Anahtar Kelimeler: Adipoz doku, hormonal bozukluklar, kadınlar, obezite

\section{Hormonal disorders and problems caused by obesity in women}

\begin{abstract}
According to World Health Organization, obesity is an illness which causes the risky and dangerous fat rate to increase in the body. Since 1980's prevelence of obesity is getting more widespread and is spreading faster day by day. High energy intake and low physical activity are the main factors in the formation of obesity. In addition to these, conditions such as genetic predisposition, psychological and socio-economic factors, age and gender increase the development of obesity. Besides, obesity poses a risk for all age groups and causes many diseases. Especially it is seen on men more the women, in many researchs it has been proven that, increased adipose tissue causes hormonal changes in the body and these changes causes to many illnesses and problems such as, polycystic over-infertility, complications during pregnancy, some types of cancer. In this compilation, effects of obesity on women and problems which are caused by these effects are explained.
\end{abstract}

Keywords: Adipose tissue, hormonal disorder, women, obesity

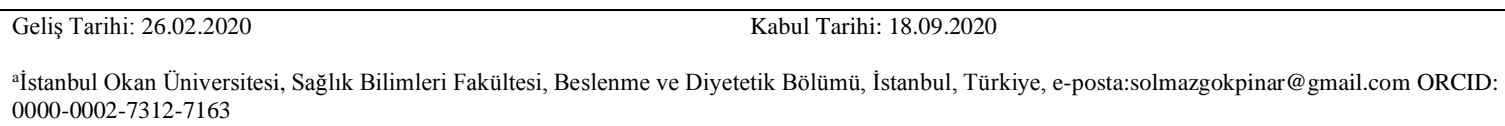

Sorumlu Yazar/Correspondence: Solmaz Nurbanu Kılıç

Atıf: Kılıç SN. Obezitenin kadınlarda sebep olduğu hormonal bozukluklar ve yol açtığı sorunlar. Sağllk ve Yaşam Bilimleri Dergisi 2020;2(2):57-65. Citation: Kilic SN. Hormonal disorders and problems caused by obesity in women. Journal of Health and Life Science 2020;2(2):57-65. 


\section{Gİiș}

Aşırı kilo ve obezite hem yetişkinler hem de çocuklar için büyük bir risk oluşturmaktadır. Günümüzde en önemli sağlık sorunlarının başında vücuttaki artmış adipoz dokuyla karakterize olan obezite yer almaktadır. Obezitedeki bu artışın neticesinde bireylerde bulaşıcı olmayan hastalıkların prevelansında da artış gözlemlenmektedir. Tip 2 diyabet, kardiyovasküler hastalıklar, hipertansiyon, inme, kas-iskelet sistemi bozuklukları gibi birçok hastalı ve sorun için ana etmeni obezite oluşturmaktadır. Bununla birlikte yapılan son araştırmalar hem dünya hem de Türkiye genelinde kadınların obezite prevelansının erkeklere göre çok daha yüksek oranda olduğunu göstermektedir. ${ }^{1,2}$

Kadınlar yaşamlarının en başından itibaren adet döngüleri, hamilelik, menopoz gibi farklı dönemlerden geçerken östrojen ve progesteron seks hormonlarında önemli dalgalanmalar yaşamaktadırlar. Bu steroid hormonların sentezlendiği dokular ise; periferik bezler, beyin ve yağ dokusudur. Kadınlarda obezite ile beraber vücut yağ dokusundaki artış hem endokrin hem de metabolik değişikliklere sebep olmaktadır. Obeziteyle birlikte artan serum insülin düzeyi; cinsiyet hormonlarında bağlayıcı globülin sentezini inhibe etmekte ve seks hormonlarının çalışma mekanizmalarında değişikliklere sebep olmaktadır. Bunun sonucunda, Polikistik over-infertilite, gebelik komplikasyonları (distosi (zor doğum), prematüre veya ölü doğum), gestasyonel diyabet, emzirme döneminde düşük kalitede anne sütü ve bazı kanser türlerinin (endometriyum, over ve meme kanseri) oluşum riskinde artış gözlenmektedir. ${ }^{3,4}$

$\mathrm{Bu}$ derlemede; vücut yăg dokusu salınımlarının kadınlarda seks hormonlarını etkileyerek nelere yol açtığına değinilmektedir.

\section{OBEZITE VE ADİPOZ DOKU}

\section{Obezitenin tanımı}

Dünya Sağlık Örgütü (DSÖ), her kesimde artmaya başlayan obeziteyi, sağlık için risk oluşturan anormal veya aşırı yağ birikimi olarak tanımlamaktadır. Birçok hastalığa ve soruna yol açmakla beraber bütün yaş gruplarını etkisi altına alan, prevelansı giderek artan, sosyal ve psikolojik birçok yöne sahip olan bir halk sağlığı problemi olarak görülmektedir. ${ }^{1}$

1980'li yıllardan bu yana hızla artma eğilimi gösteren obezite, 2016 yilına gelindiğinde ortalama on yetişkinden dördünün kilolu, birinin obez olduğu ve birçok ülkede yetişkinlerde görülen obezitenin \%13'ü aştığı bir noktaya gelmiştir. Eğer gelişim hızı bu oranda devam ederse 2030 yılına gelindiğinde Dünya genelinde 2,16 milyar aşırı kilolu ve 1,12 milyar obez birey olabileceği öngörülmektedir. ${ }^{1,5}$
Obezitenin oluşmasının temelinde her ne kadar fazla enerji alımı ve düşük fiziksel aktivite varlığı olsa da; ailede obezite varlığı-genetik faktörler, psikolojik etmenler, sosyoekonomik durum, uyku bozuklukları, yaş, cinsiyet gibi birçok etmen obezitenin gelişimde etkin olarak rol oynayabilmektedir. ${ }^{6}$

\section{Obezitenin Sınıflandırılması}

Obezitenin ve ona bağlı kronik hastalık gelişim risk faktörlerinin belirlenmesinde en kolay ve en yaygın olarak kullanılan Beden kütle indeksi (BKİ) sınıflandırmasıdır. BKİ sınıflandırması DSÖ’nün kriterlerine göre yapılmaktadır. Hesaplama yapılırken; kişinin kilogram cinsinden ağırlığı, boyunun metrekaresine oranlanır $\left(\mathrm{kg} / \mathrm{m}^{2}\right)$. Çıkan sonuca göre, aşağıda yer alan tablodaki (Tablo 1) verilerle kişinin obezite derecesi sinıflandırılmaktadır. Buna göre bireylerin normal olarak değerlendirilen BKİ değerleri 18.5 ile $24.9 \mathrm{~kg} / \mathrm{m}^{2}$ arasında kabul edilirken; BKI değerinin $18.5 \mathrm{~kg} / \mathrm{m}^{2}$ 'nin altında bulunması zayıflık, $30 \mathrm{~kg} / \mathrm{m}^{2}$ 'nin üzerinde bulunması ise obezite olarak değerlendirilmektedir. ${ }^{1}$

Tablo1. Beden kütle indeksi sınıflandırması ${ }^{1}$

\begin{tabular}{rc}
\hline \multicolumn{1}{c}{ BKI } & Sinıflandırma \\
$\leq 18.5$ & Zayıf \\
$18.5-24.9$ & Normal \\
$25.0-29.9$ & Kilolu \\
$30.0-34.9$ & 1. derece obez \\
$35.0-39.9$ & 2. derece obez \\
$\leq 40$ & 3. derece obez \\
\hline
\end{tabular}

Vücuttaki adipoz dokunun dağılımı da obezitenin belirlenmesinde etken rol oynamaktadır. Adipoz dokunun vücudun alt kısmında toplanmasına jinoid tip obezite denirken, üst kısmında toplanmasına ise android tip obezite denilmektedir. Genellikle erkeklerde android tip obezite görülürken kadınlarda jinoid tip obezite görülmektedir. Bel çevresinin erkeklerde $102 \mathrm{~cm}$, kadınlarda ise $88 \mathrm{~cm}$ 'in üzerinde olması bireylerde obezite varlığını gösteren en önemli ölçütlerdir. Ayrıca bel-kalça oranı erkeklerde 1'in; kadınlarda ise 0.8 'in üzerinde olması da obezitenin ölçütlerinden biri olarak kabul edilmektedir. ${ }^{6}$

\section{Adipoz Dokunun Yapısı}

Kan damarlarından, sinirlerden ve bağ dokularından oluşmuştur. Obez olmayan bir bireyde ortalama 30-50 milyar bulunan adipoz doku hücreleri, çeşitli hücrelere dönüşerek vücutta kompoze olan kök hücrelerden meydana gelmiştir. $\mathrm{Bu}$ dönüşüm şu şekilde gerçekleşir; ${ }^{6}$

Kök Hücre $\rightarrow$ Adipoplast $\rightarrow$ Preadipozit $\rightarrow$ Adipozit 
Preadipozitlerin adipozit dokusuna farklılaşması ömür boyunca süre gelebilmektedir. Bu özellik adipoz dokuya hiperplastik özellik kazandırmaktadır. Ayrıca vücutta artan enerji, adipozitlerde yer kalmadığ zaman, adipozitler daha da genişler ve hipertrofik bir hale gelir. Adiposit sayısı ve morfolojisi, lipid alımı, esterifikasyon, lipoliz ve preadipozitlerin farklılaşmasıyla homeostaz sağlanmış olur. ${ }^{3}$

Adipoz dokunun fonksiyonları üç başlıkta toplanabilmektedir; trigliserid depolaması ve yağ asidi salınımı da dahil olmak üzere lipid metabolizmasında, karaciğer ve diğer dokulardaki glikoz metabolizmasına katılan gliserol ve yağ asidlerini serbest bırakarak trigliserid katabolizmasında ve adipositler, hormonlar, sitokinler ve spesifik biyolojik fonksiyonlara sahip diğer proteinleri içeren adipokinleri salgılamak gibi vücut içerisinde etkinliği bulunmaktadır. ${ }^{7}$ Adipoz dokunun büyük bir kısmı subkutan (deri altı) kısımda yer alırken visseral dokuda da (abdominal bölge organlarında) gelişim göstermektedir. Visseral dokuda adipoz doku gelişimi, kardiyovasküler ve metabolik komplikasyonlar için riski arttırırken, subkutan dokunun ise halen tamamıla tanımlanmamış koruyucu etkileri mevcuttur. $\mathrm{Bu}$ yüzden vücutta bulunan adipoz doku varlığından ziyade, adipoz dokusundaki artışın lokalizasyonu daha büyük önem taşımaktadır. ${ }^{8,9}$ Visseral adipoz doku ve subkutan adipoz dokusu arasında adipokin sentezi ve salgılanması bakımından da bazı farklılıklar olduğu belirtilmektedir. Örneğin; visseral dokuda, IL-6 (İnterlökin-6) ve PAI-1 (Plazminojen Aktivatör İnhibitör-1) daha yüksek konsantrasyonlarda gözlemlenirken, subkutan dokuda leptin ve adiponektin daha yüksek konsantrasyona sahiptir. ${ }^{10}$

Vücutta işlevsel ve metabolik farklılıkları bulunan 2 çeşit yağ dokusu bulunmaktadır:

\section{Kahverengi Adipoz Doku}

Küçük memelilerde ve neonatal süreçte (\%2-3) insanlarda bulunan kahverengi adipoz doku; ileri yaş, yüksek BKİ değeri ve visseral yağ dokusu varlığıyla azalmaya başlar. Fakat son y1llarda sempatik sinir sistemi uyarımı ve soğuğa maruz kalmanın kahverengi adipoz dokuda artışa sebep olduğu bildirilmektedir. İçeriğinde çok fazla UCP1 (uncoupling protein-1) içeren mitokondri bulunmaktadır. $\mathrm{Bu}$ proteinin ekspresyonu sonucunda vücut çerisinde enerji harcama mekanizmasında ve 1si dengesini korumada görevlidir. ${ }^{11,12}$ Kahverengi adipoz doku çeşitli uyarıcılarla birlikte metabolizmada değişikliklere sebep olmaktadır (Tablo 2).

\section{Beyaz Adipoz Doku}

Vücut içerisinde özellikle intraperitoneal alanda ve cilt altında bulunmaktadır. Fazla olan enerjinin trigliserit olarak depolandığı yerlerdir. Pleiotropik yapısı sayesinde, adipozitlerden sayısız hormon, büyüme faktörü, enzim, sitokin, tamamlayıcı faktör ve matris proteinlerini salgılayarak adipoz dokunun metabolik ve endokrin özellik göstermesini sağlamaktadır. Olgunlaşmış beyaz adipositler, toplam beyaz adipoz doku hücrelerinin üçte biri ile üçte ikisini temsil eder. Kalan hücreler ise; fibroblastları, endotel hücreleri, makrofajları ve preadipositleri kapsayan stromal vasküler fraksiyonun bir parçasıdır. Kişilerdeki obezite varlığı ile toplam vücut ağırlığının \%10-50'sini oluşturabilmektedir. ${ }^{10,12,13}$

Ayrıca bireylerde obezite ve adiposit boyutunda (adiposit hipertrofisinde) artışla doku inflamasyonu ve makrofaj infiltrasyonunda artış gözlemlenmektedir. Normal visseral adipoz dokuda makrofajların oranı $\% 15$ iken; obezite varlığında \%45-60'a kadar yükselebilmektedir. ${ }^{12}$ Beyaz adipoz doku tarafindan salgilanan ana adipokinler ve bunların metabolizmadaki rolü Tablo 3 'te yer almaktadır.

Tablo 2. Uyarıcı altında kahverengi yăg dokusu tarafindan üretilen başlıca faktörler ve rolleri ${ }^{12}$

\begin{tabular}{cc}
\hline Faktörler & Metabolizmadaki Etkisi \\
\hline VEGF-A (Vasküler & Sempatik aktivasyona yanıt olarak \\
Endotelyal Büyüme & anjiogenez \\
Faktörü-A) & \\
IGF-I (İnsülin & \\
Benzeri Büyüme & Kahverengi adiposit öncüsünde artış \\
Faktörü-1) & \\
FGF-2 (Temel & Kahverengi adiposit öncüsünde artış \\
Fibroblast Büyüme & Enflamasyon \\
Faktörü-2) & Enflamasyon \\
IL-1 (İnterlökin-1 $\alpha$ ) & dokuda duyarlık \\
IL-6 (İnterlökin-6) & Adrenerjik etkiye kahverengi Adipoz \\
BMP8b geni & Prostaglandinler sentezi, lipofilik \\
Lipokalin & moleküllerin taşı1cısı (tiroid \\
prostaglandin D & hormonları, retinoik asit) \\
sentezi & Kahverengi adipoz doku endojen \\
& rolünün termojenik aktivasyonu \\
olduğu düşünülmektedir.
\end{tabular}

Tablo 3. Beyaz adipoz doku tarafindan salgılanan ana adipokinler ve bunların metabolizmadaki rolü ${ }^{12}$

\begin{tabular}{cc}
\hline Adiponektin & Rolü \\
\hline MCP-1 & Makrofaj alımının stimülasyonu \\
TNF- $\alpha$ & Enflamasyon, insülin direnci \\
IL-6 & Enflamasyon, insülin direnci \\
IL-1 $\beta$ & Enflamasyon, insülin direnci \\
Leptin & İştah azalması (obezite ile artışında \\
Resistin & direnç gerçekleşir) \\
ANGPTL2 & Enflamasyon, insülin direnci \\
RBP-4 & Enflamasyon, insülin direnci \\
Anjiyotensinojen & İnülin direnci \\
Adipsin & Enflamasyon, insülin direnci \\
Visfatin & İnsüline benzeyen hormon \\
Adiponektin & Yağ asidi oksidasyonu, hepatik glikoz \\
Omentin & üretiminde azalma (obezite ile azalma) \\
IL-10 & İnsülin duyarlılığ (Obezite ile azalma) \\
SFRP5 & Anti-enflamasyon (obezite ile azalma) \\
& İnsülin duyarlılığ1, anti-enflamasyon \\
& (obezite ile azalma) \\
\hline
\end{tabular}




\section{Adipoz Dokudan Salgılanan Yapılar}

Başlangıçta adipoz dokunun sadece enerji depolaması, 1S1 yalıtımı ve termoregülasyon amaciyla vücut içerisinde fonksiyon kazandığı düşünülmekteydi. Son yıllarda yapılan çalışmalarda ise adipoz dokunun sadece bir depo hücresi değil; aynı zamanda "adipokinler" olarak adlandırılan yapıların hem otokrin/parakrin hem de endokrin etkinliği olan biyoaktif peptidlerin sentezinde ve salınımında etkin olarak rol oynadığı bilinmektedir. Adipoz dokunun bu etkinliği onların, glikoz ve lipid metabolizmasında, enerji homeostazında, beslenme davranışı kontrolünde, insülin duyarlılığının sağlanmasında, inflamasyon ve bağışıklık gibi birçok olayda etkin olarak rol almasını sağlamaktadır. ${ }^{8}$ Bunları bazılarını belirtecek olursak;

Leptin: Leptin, besin alımını engelleyen ve beyindeki nöronal yolaklarla, özellikle de hipotalamustaki yolaklarla etkileşerek enerji tüketimini uyaran, adipositlerden salgilanan bir hormondur. Tokluk sinyali vermesine karşın, vücuttaki adipoz doku varlığının artmasıyla artan leptin salınımı ile leptin direnci oluşmaktadır. Bu sebeple, obez bireylerde leptinin yüksek seviyeleri, leptin reseptör sinyali kusurlarına, nöronal devrelerde aşağı akım blokajına ve kan-beyin bariyerinde leptin taşınımındaki kusurlara bağlı olarak iştahı inhibe edemez. ${ }^{10,14}$

Adipoz dokusunun gramı başına ortalama leptin salınımı, obezlerde normal kilolu bireylere göre iki kat daha fazladır. Ancak adipoz doku hücrelerinin boyutu obezlerde iki ila dört kat büyüdüğünden, adipoz doku hücresi başına ifade edildiğinde, leptin sekresyonu obezlerde normal kilolu bireylere oranla yedi kat daha fazla olduğu bildirilmektedir. ${ }^{15}$

Leptin, glukokortikoidler, akut enfeksiyon ve proinflamatuar sitokinlerin varlığı ile artış gösterirken; soğuğa maruz kalma, adrenerjik stimülasyon, büyüme hormonu (GH), tiroid hormonu, melatonin, sigara ve tiazolidindionların varlığı ile azalmaktadır. Kadınlarda leptin düzeyi erkeklerden daha yüksektir. Bunun nedeni, kısmen androjenlerin inhibisyonuna, östrojen uyarımına ve leptin ekspresyonunda depoya bağlı farklılıklar olmasına bağlanmaktadır. Leptin sentezi visseral adipoz dokuya oranla subkutan adipoz dokuda daha fazladır. $\mathrm{Bu}$ sebeple, kadınlarda leptinin dolaşımdaki yüksek konsantrasyonunun kısmen daha yüksek oranda olması subkutan adipoz dokunun varlığı ile ilişkilendirilmektedir. ${ }^{10}$

Adiponektin: Adiponektin, yeni doğanlar ve beslenme yetersizliği olanlar haricinde, sadece adipoz dokudan salgılanmaktadır. İnsanlardaki serum adiponektin konsantrasyonu ile visseral adipoz doku düzeyi arasında kuvvetli bir negatif ilişki vardır. Hormon, reaktif oksijeni azalmasını sağlayan bir antioksidandır. Adiponektin, endotelyal azot oksit üretimini arttırır ve trombosit agregasyonunu ve vazodilatasyonunu azaltarak vaskülatürü korumaya yardımcı olmaktadır. $\mathrm{Bu}$ etkisi sayesinde kardiyovasküler hastalıklarda koruyucu etki göstermektedir. Ayrıca Adiponektin kaslarda glikoz kullanımı, yağlı asit oksidasyon gibi metabolik süreçlere katılmaktadır ve insülin duyarlılığını arttırarak insülin direncinin oluşumunu da engellemektedir. ${ }^{10,16,17}$

İnsan plazma adiponektin konsantrasyonu adipoz doku varlığı dışında cinsiyetle de ilişkilendirilmektedir. Kadınlarda erkeklerden daha yüksek olduğu belirtilmektedir. Bu cinsel dimorfizm pubertal gelişim sırasında serum androjenlerle ilişkili olarak gelişir. Sağlıklı kadınlarda adiponektin konsantrasyonunun yaşla birlikte önemli derecede arttığı belirtilmektedir. Eğer obezite durumu varsa normal kilolu olan kadınlara oranla çok daha düşük bir seviyede seyretmektedir. ${ }^{17}$

Resistin: İçeriğinde yüksek miktarda sistein bulunan bir peptittir. Resistin, sadece adipositler tarafindan değil aynı zamanda; kaslarda, pankreas adacıklarında, mononükleer hücrelerde üretilebileceği bildirilmektedir. Ayrica lipopolisakkaritlerle, proinflamatuar sitokinlerle (IL-1, IL-6 ve TNF- $\alpha$ ), hiperglisemiyle veya enfeksiyon sırasında bağışıklık sisteminin uyarılmasıyla resistin üretiminde artış gerçekleşmektedir. ${ }^{10,16}$

Dolaşımdaki resistin seviyelerinin, obez fare modellerinde ve obez insanlarda anti-diyabetik ilaç olan rosiglitazone ile azaldığı, diyetle ve genetik etkilerle obez olanlara anti-resistin antikorunun uygulanmasının serum glikoz ve insülin düzeylerinde iyileşmeyi sağladığı bildirilmektedir. Bunun yanında resistinin diyabetik komplikasyonlar ve diyabet patogeneziyle ilişkili olduğu belirtilmektedir. ${ }^{10}$

TNF- $\alpha$ : TNF- $\alpha$ bağışıklık fonksiyonunu, hücre farklılaşmasını, proliferasyonu, apoptoz ve enerji metabolizmasını ve birçok hücresel ve biyolojik işlemin düzenlenmesini sağlayan bir sitokindir. Eskiden sadece adipoz dokudan salınımı gerçekleştiği düşünülürken, yakın zamanlarda ana kaynağının stromal vasküler fraksiyondaki makrofajların olduğu bildirilmektedir. Ayrica TNF- $\alpha$ 'nın hepatositlerde ve adipoz dokusunda, insülin sinyalizasyonunu bozabileceği belirtilmektedir. Obezite ile gelişen adipoz dokudan salınan TNF- $\alpha$ 'nın mesajcı RNA (mRNA) ekspresyon düzeylerinin ve insülin direncinin patogenezinde güçlü bir şekilde rol oynadığını belirtilmektedir. ${ }^{10,18}$

IL-6: IL-6 düzeyindeki artış, tip 2 diyabet, BKİ'de artış ve plazma içindeki artmış serbest yağ asidi konsantrasyonları ile ilişkilidir. Obez adipoz dokusunda IL-6 ekspresyonunda artış olmaktadır. Obez bireylerden yağ dokusunda IL-6 ekspresyonu adipoz dokusu normal düzeyde olan bireylerden ortalama 10 kat fazla olduğu belirtilmektedir. Adipoz 
doku salınımları serumdaki düzeylerinin \%30'unu karşılamaktadır. Visseral adipoz dokudan salınımı subkütan adipoz dokudan daha fazladır. TNF- $\alpha$ ve interlökin-1 tarafindan uyarılmaktadır. Yüksek konsantrasyonu enflamatuvar etkisi nedeniyle koroner arter hastalığı ve ateroskleroz riskini arttırdığ bildirilmektedir. Ayrica IL-6, lipaz lipoproteini inhibe eder, lipoliz üretir ve glikoz alımını arttırmaktadır. ${ }^{10,15,19}$

Vistafin: Adipositler tarafindan üretilmesinin yanında visseral adipoz doku makrofajları tarafindan ve küçük miktarlarda ise subkutan adipoz doku tarafindan üretilmektedir. Visfatin, mRNA ekspresyonu ve preadipositlerin adipositlere dönüşümü sürecinde büyük ölçüde artış gözlemlenmektedir. ${ }^{10}$ Visfatinin başlica fonksiyonu enerji metabolizması ve doğuştan gelen bağışıklık ile ilişkilidir. Ayrıca son dönemde proenflamatuar adipositokin olarak belirtilmektedir. Böylece lökositlerin aktivasyonunu sağlar ve TNF- $\alpha$ ve IL-6 üretimini uyarmaktadır. ${ }^{10}$

\section{KADINLARDA OBEZITEYLE OLUŞAN HORMONAL DEĞİŞIKLIKLER VE SORUNLAR}

Yağ dokusunun varlığı kadınlarda üreme sağlığı ve hormonal gelişim için çok önemlidir. Fakat fazla miktarda vücutta bulunan yağ dokusu birçok soruna yol açarak kadınlarda cinsel gelişimi olumsuz yönde etkilemektedir. $^{20}$

\section{Polikistik Over-İnfertilite}

Polikistik over (PCOS), özellikle üreme çağında olan kadınlarda ortaya çıkan yaşam boyu etkileyen, yaygın, heterojen ve kalitsal bir endokrin bozukluktur. PCOS varlığında kadınlarda üreme sağlığında bozulmalar (kısırlık, hiperandrojenizm, hırsutizm), metabolik hastalıklar (insülin direnci, bozulmuş glikoz toleransı, tip 2 diabetes mellitus, kardiyovasküler hastalıklar) ve psikolojik sorunlar (artmış anksiyete, depresyon ve kötüleşen yaşam kalitesi) gibi farklı klinik etkilerin oluşmasına neden olmaktadır. İlk olarak 1935'te amonere ve buna bağlı infertilite, hirsutizm (aşırı kıllanma) ve büyümüş yumurtalıkta çok sayıda kistle karakterize bir hastalık olarak gündeme gelmiştir. ${ }^{21,22}$ Prevelansı \%4-18 arasında gözükebilen PCOS'un patofizyolojisinde obezitenin etkili olabileceği bildirilmektedir. Bununla beraber gelişiminde etkili olabilecek etmenler ise; hiperandrojenizm, artan lüteinizan hormon (LH) ve insülin direnci oluşturmaktadır. Ayrıca adipoz dokudan salınımı gerçekleşen leptin, adiponektin, resistin ve visfatin de PCOS'un patofizyolojisinde etkin olarak rol oynayabilmektedir. ${ }^{22,23}$

Visseral adipoz dokudaki artış insülin duyarlılığını etkilemektedir. Subkutan adipoz dokuda standart sapmadaki her bir artışın insülin direncini \%48 oranında azaltırken; visseral adipoz dokudaki artışın ise $\% 80$ oranında insülin direncini arttırdığı belirtilmektedir. Adipoz doku salınımlarının birçoğu inflamasyonu arttırıcı özellik göstermektedir. İnflamasyon, dolaşımda veya dokuda artmış sayıda beyaz kan hücresi veya artmış inflamatuvar sitokin seviyesi ile karakterize fizyolojik bir süreçtir. Bu süreçte, çeşitli mekanizmalar yoluyla adipositlerde ve hepatositlerde insülin sinyal aktivitesini inhibe etmektedir. Ayrıca, $88 \mathrm{~cm}$ 'den fazla bel çevresine sahip olan PCOS'lu kadınlarda artmış visseral yağın hiperandrojenemi ile ilişkili olduğu ve kilo kaybı veya insülinin periferik duyarlılığını arttıran ilaçlarla insülin direncinin azalmasının, hormonal sapmaları ve ovülasyonu artırdığı belirtilmektedir. ${ }^{24-26}$

Serumdaki insülin düzeyindeki artışın neticesinde, insülin benzeri büyüme faktörü bağlayıcı protein-1 (IGFBP-1)'in baskılanmasına sebep olarak, serumdaki serbest insülin benzeri büyüme faktörü (IGF-I) seviyesini arttırmaktadır. IGF-I' in serumdaki artışı ise vücutta androjen salınımını uyarmaktadır. Bu durum PCOS oluşumuna sebep olmaktadır. ${ }^{27}$ Yapılan çalışmalarda, PCOS'a sahip olan kadınların \%3040'1nda obezite ve \%50-70'inde insülin direncinin etkili olduğu belirtilmektedir. PCOS'un oluşumundaki etmenleri incelersek, bu oranlarla karşılaşmamız olağan bir durumdur. ${ }^{28,29}$ Bununla beraber obez olan kadınlarda PCOS'un etkileri daha fazla görülmektedir. Yapılan bir meta-analizde normal kilolu kadınlarla kıyaslandığında PCOS'lu obez kadınlarda hirsutizm haricinde değerlendirilen metabolik ve üreme ölçü sonuçları daha kötü çıkmıştır. ${ }^{30}$

PCOS varlığında anovulasyonla beraber kadında infertilite de görülmektedir. Bu durumla birlikte, eğer kadın obez ise diğer faktörlerin de etkisiyle infertilite gelişim riski üç kat artmaktadır. Bunun temelinde ise adipoz doku salınımlarından leptin, adiponektin, resistin ve visfatin salınımı; androjen, luteinizan, insülin gibi hormonların serumdaki düzeyinin etkilenmesi ile cinsiyet hormonu bağlayıcı globulin (SHBG), büyüme hormonu (GH) ve IGFBP'nin azalması ve leptin seviyelerinin artmasıdır. Sonucunda da anovulasyon durumun gerçekleşmesidir. PCOS'lu kadınlarda hastalığa bağlı komplikasyonları indirgemek için beslenme ve yaşam tarzında değişikliğin sağlanması gerekmektedir. ${ }^{20,31}$

\section{Gebelik Komplikasyonları}

DSÖ’ye göre; gebelikte obezite görülme prevelansı $\% 1.8$ ile \%25.3 arasında değişmektedir. Obezite kadınlar için risk oluşturmasının yanında gebe olan kadınlar için daha da büyük bir risk oluşturmaktadır. $\mathrm{Bu}$ süreçte; bebeğin gelişimi olumsuz yönde etkilenmekte, gebelik süresi kısalmakta ve gebelik sonrasında gebede kronik hastalıkların oluşum riski artmaktadır. Fetal ve maternal yapıların gözlenmesinde kullanılan ultrasonografik gözlem yöntemi, obez 
kadınlarda artan adipoz doku sebebiyle net bir sonuç verememektedir. Buna bağlı olarak anatomik yapının tam olarak gözlemlenememesi potansiyel risklerin ve fetal anomalilerin tespitini önlemektedir. ${ }^{1,32}$

Obez gebelerde erken dönemde gebelik kaybı riski çok yüksektir. Ayrıca bebekte fetal malformasyonlar, makrozomi, distosi (zor doğum), prematüre ve ölü doğum gibi sorunlar da oluşabilmektedir. Bununla beraber gebeler, doğum sırasında aşırı kanama, enfeksiyon ve buna bağlı daha uzun süre hastanede kalma riskleri ile karşı karşıyadır. Ayrıca İsveç’te yapılan 12 yıl süren bir kohort çalışmasında 1.049,582 bebek incelenmiş ve ortaya çıkan sonuca göre; nöral tüp defekti, kardiyak defektler ve orofasyal yarıklara ek olarak, hidrosefali, anal atrezi (anüs çıkışının kapalı olmasi), hypospadias (doğumsal olarak üretral açıklığın olması gereken yerde olmaması), kistik böbrek, pes ekinovarus (çarpık ayak), omfalosel (barsağın göbeğe fitıklaşması) ve diaphragmatic hernia (diyaframın fitıklaşması) riskinin arttırdığı bildirilmiştir. $^{32}$

Gebede görülen obezitenin, bebekte nöral tüp kusurları, kalp malformasyonları ve orofasiyal yarıkların oluşumunda risk oluşturabileceği üzerinde durulmaktadır. Nöral Tüp Defektinin (NTD) gelişimindeki ana mekanizmanın; yetersiz emilimle beraber maternal metabolik talebin fazlalaşması, kronik hipoksi, serum trigliserit, ürik asit, östrojen ve insülin seviyelerindeki artış olduğu düşünülmektedir. $\mathrm{Bu}$ etkilerin oluşumuyla fetal folik asit gereksiniminin karşılanamadığ $\breve{~ b e l i r t i l m e k t e d i r . ~}^{33}$

Kadının obezite seviyesi ne kadar yüksekse, konjenital bir kalp kusuru olan bir bebek doğurma ihtimalinin de o kadar yüksek olduğu bildirilmektedir. Orta derecede obez olan kadınların \%11'i kalp krizi geçiren bir çocuğa sahip olma ihtimali varken; morbid obez kadınlarda ise bu oranın \%33'ü bulduğu belirtilmektedir. $^{34}$

Gebede diyabet olsun veya olmasın obezite varlığında, insülin direnciyle beraber fetal glukoz ve insülin düzeylerindeki artış makrozemi (bebeğin 4000 gr'dan fazla ağırlıkta doğması) gelişimine neden olmaktadır ve bu tüm doğumların \%12'sini etkilemektedir. Obez gebelerin bebekleri normal ağırlıktaki gebelerin bebekleri ile karşılaştırıldığında iki kat daha fazla makrozomi oluşum riski vardır. Makrozomili doğan bebeklerde, omuz distosisi, klavikula kırıkları ve brakiyal pleksus yaralanmaları ve postpartum süreçte yenidoğan yoğun bakım servisinde yatma riski artmaktadır. $^{35}$

\section{Gestasyonel Diabetes Mellitus}

Gebelik öncesinde diyabet tanısı almamış fakat gebelikle beraber 2 . veya 3 . trimesterde gebede hiperglisemi oluşmasına "gestasyonel diabetes mellitus (GDM)" denir. Tüm gebeliklerde \%1-14 oranında prevelansa sahiptir. ${ }^{36}$ GDM hem gebenin hem de bebeğinin kısa ve uzun vadede sağlıklarını olumsuz yönde etkileyebilecek bir durumdur. GDM'nin maternal komplikasyonları arasında Tip 2 diyabet, metabolik sendrom ve kardiyovasküler hastalık gelişme olasılığında artış bulunmaktadır. GDM'den etkilenen gebelikler, makrozomi, omuz distosisi, doğum yaralanmaları ve hipoglisemi gelişme riski altındadır. Ayrıca ileriki dönemlerde, GDM ile doğan bebekler aşırı kilo alma ve bozulmuş glukoz toleransına sahip olma gibi riskler de taşımaktadır. Obez gebeler ise; düşük yapma, ölü doğum, preeklampsi, sezeryanla doğum, hipertansiyon, enfeksiyon ve tromboembolik hastalık gibi birçok gebeliğe bağlı durumlarla karşı karşıya kalabilmektedir. ${ }^{37}$

Bebeğin gelişim sürecinde gebede birçok hormon düzeyinde değişiklik oluşmaktadır. Özellikle östrojen, kortizol, progesteron, prolaktin gibi hormonların serumdaki artışı insülin düzeyine olan ihtiyacı arttırmaktadır. $\mathrm{Bu}$ süreçte pankreasın $\beta$ hücreleri insülin salınımında yetersiz kalabilmektedir. $\mathrm{Bu}$ yetersizlikle ilk aşamada glikoz intoleransı gelişir, sonrasında hücre içerisine giremeyen glikozun serumdaki düzeyi artarak hiperglisemi oluşmaktadır. ${ }^{36,38}$

Obezite, GDM gelişiminde önemli risk faktörü olarak görülmektedir. Günümüzde obezitenin prevelensındaki artış bunu daha da güçlendirmektedir. Bir milyon sekiz yüz seksen dört gebe üzerinde yapılan bir kohort çalışmada (Tablo 4); normal ağırlığa sahip olan gebelerde GDM gelişim riski \%4 iken, obez olan gebelerde bu risk \%19 olarak belirtilmiştir. ${ }^{37-39}$

Tablo 4. Gebelik öncesi BKİ ile gestasyonel Diabetes Mellitus ilişkisi ${ }^{39}$

\begin{tabular}{ccc}
\hline $\begin{array}{c}\text { Gebelik } \\
\text { oncesi BKI }\end{array}$ & n & $\begin{array}{c}\text { Gestasyonel Diabet Mellitus } \\
(\boldsymbol{\%})\end{array}$ \\
\hline Zayıf & 151 & 3 \\
Normal & 1,172 & 4 \\
Aşrı kilolu & 331 & 11 \\
Obez & 152 & 19 \\
\hline
\end{tabular}

Gebelik durumu olmaksızın obezite varlığında TNF- $\alpha$, leptin, adiponektin ve resistin gibi faktörlerin düzeylerindeki değişiklik insüline olan ihtiyacı arttırarak insülin direncinin oluşmasına yol açmaktadır. İki durumunda beraber gerçekleşmesi insüline olan ihtiyacı daha da arttırarak GDM oluşumunu hızlandıran bir etmen olmasına yol açmaktadır. ${ }^{40}$

GDM'nin ilerleyen zamanlarda bebeklerde obeziteye sebep olduğu bildirilmektedir. Artan maternal leptin düzeylerinin bebekte iştah ve metabolik homeostaz regülasyonunu etkilediği belirtilmektedir. Leptin, gıdaların alımını azaltmak ve enerji harcamasını artırmak için hipotalamusta görev yapmaktadır. 
Hamilelik sırasında hiperleptinemi, özellikle hipotalamusta gelişen fetal dokulardaki leptin duyarlılığını azaltabilir. Leptin duyarlılığında bu kalıcı değişiklikler, obezite döngüsünü sürdürerek bebeklerde enerji dengesi için uzun vadeli negatif etkilere sebep olabilmektedir. ${ }^{41}$

\section{Anne Sütü ve Emzirme}

İlk süt gelişimi gebelik sürecinde başlamaktadır. Kazein ve laktozdaki artışla beraber prolaktin değerlerinde de artış olur fakat progesteron hormonu süt salınımını baskılamaktadır. Bu sürece, "laktojenez I" denir. Doğumun gerçekleşmesiyle birlikte progesteron hızla düşerek serumdaki düzeyi azalmaya başlar ve memeden süt gelmeye başlar. $\mathrm{Bu}$ süreç de "laktojenez II" olarak adlandırılmaktadır. ${ }^{42}$ Fakat obez annelerde emzirmeye eğilimin azaldığı ve laktojenez II evresinin uzadığı belirtilmektedir. Adipoz doku steroid hormonlar için depo görevi görmektedir. Gebelik döneminde adipoz dokunun progesteron hormonunun depolanması ve progesteron metabolizmasının düzgün bir şekilde kontrol edilememesi nedeniyle laktogenez II evresinde gecikmeler olmaktadır. $\mathrm{Bu}$ sebeple laktojenez II evresi için gerekli olan progesterondaki ani düşüşü sağlanamamakta ve serum prolaktin düzeyinin uygun bir seviyeye gelememesine neden olarak memeden süt gelmemektedir. ${ }^{43}$

Tüm bunlarla beraber, son yıllarda obez annelerin sütünde bulunan glukoz, insülin, leptin, IL-6 ve TNF$\alpha$ gibi hormon ve sitokinlerin bir aylıkken bebeklerde yağ kütlesini ve yağsız vücut kompozisyonunu etkileyebileceği bildirilmiştir. Yapılan bir çalışmada k1z bebekleri emziren obez annelerin sütünde bulunun insülin içeriğinin, kız çocuğuna sahip normal kilolu annelere göre \%229 daha fazla bulunduğu saptanmıştır. Ayrıca annenin sahip olduğu BKİ değerine göre, anne sütü içerisinde bulunan leptin düzeyinin de doğru orantılı olarak arttığ belirtilmektedir. $\mathrm{Bu}$ bulgularla, annedeki obezite varlığının anne sütündeki insülin ve leptin düzeyini etkileyerek "obezojenik anne sütü" oluşturmasına neden olduğu düşünülmektedir. ${ }^{44}$

Ayrıca BKİ'deki artış gebenin, vajinal doğum yapma olasılığını ve vajinal doğum başarısını da azaltan bir etmen olarak rol oynamaktadır. Bununla beraber sezaryen doğumun gecikmiş laktogenez veya düşük süt sağlama olasılığında artışa neden olduğu belirtilmektedir. ${ }^{32,43}$

Emzirme süreci ve anne sütü kalitesi birçok faktörle değişiklik gösterebilmektedir. Bununla beraber obez gebelerde laktasyonun azalmasından sorumlu olabilecek birçok psikolojik, davranışsal ve kültürel neden bulunmaktadır. Bu yüzden obez gebelerde emzirme sürecinin başarılı olabilmesi için laktasyon döneminde destekleyici ortamların sağlanması gerekmektedir. ${ }^{43}$

\section{Bazı Kanserlerin Gelişimi}

Obezite tek başına tüm dokulardaki kanser riskini aynı oranda artırmadığı halde, vücutta aşırı adipoz doku varlığı ve kanser arasında direkt ilişki olduğu bildirilmektedir. Tüm kanserlerin ortalama \%20'sinin obezite nedeniyle gerçekleştiği düşünülmektedir. Kadınlarda obezite ile ilişskilendirilen kanserler; endometriyum, serviks ve meme kanserleridir. ${ }^{45,46}$

Premenopozal kadınlarda östrojen yumurtalıkta sentezlenirken; menopozdan sonra ise adipoz dokudaki androjenlerin aromatizasyonu ile üretilmektedir. Ayrıca, obez kadınlarda SHBG'nin hepatik sentezinin azalması serumda bağlanmamış östrojende de artışa yol açmaktadır. Obeziteyle beraber östrojen düzeyindeki bu artış kadınlarda kanserojenik etkiye sebep olmaktadır. ${ }^{46}$ Östrojen seviyesinden bağımsız olarak, obezite ile insülin, IGF-1, TNF- $\alpha$, IL-6, adiponektin ve leptin düzeylerindeki değişiklikler kanser dokularında mitojenik etkiye de yol açmaktadır. $^{46,47}$

Endometriyum kanseri obezite ile ilişkilendirilen ilk kanser türüdür. 2010 yılında yayınlanan bir metaanalizde, BKI'si $27 \mathrm{~kg} / \mathrm{m}^{2 \prime}$ nin üzerinde olan kadınlarda her $5 \mathrm{~kg} / \mathrm{m}^{2}$ artışta endometriyum kanseri riskinin 1.60 (\%95 CI 1.52-1.68) olduğu bildirilmiştir. Dünyadaki obezite eğilimlerine bakıldığında, endometriyum kanserinin \%40'ından fazlasının aşırı kiloya ve şişmanlığa bağlanabilmektedir. Prospektif veriler, endometriyum kanseri için mortalite hızlarının; BKI değeri 30-34.9 olanlarda 2.53 (95\% CI 2.02-3.18), BKI değeri 35-39.9 olan aşırı obezlerde 2.77 (95\% CI 1.83-4.18) ve BMI değeri 40 üzerinde olanlarda 6.25 (\%95 CI 3.75-10.42) olduğu belirtilmektedir. ${ }^{46}$

Serviks kanserinin oluşumu çeşitli nedene bağlıdır. Oral kontraseptifler, multiparite (çok fazla doğum yapma), sigara, düşük bağışıklık, beslenme durumu ve eşlik eden bulaşıcı hastalıklar da dahil olmak üzere patojenezle ilişkili birçok faktör olmasının yanında HPV virüsü serviks kanseri vakalarının neredeyse \%95'inin nedeni olarak gösterilmektedir. Bununla beraber serviks kanserinin gelişiminde obezitenin rolü de çok büyüktür. Obeziteyle gelişen adipoz dokunun hormonal etkileriyle servikal adenokarsinom patogenezinde rol oynayabileceği bildirilmiştir. Fakat buna rağmen obez kadınların serviks kanseri taramasına katılımı \%40'dan daha düşük olduğu belirtilmektedir. Obez kadınlarda görülen, negatif beden imgesine sahip olma, utanç duyma, sağlık personelinden algılanan saygı eksikliği veya sürekli kilo kaybı üzerine tavsiye duymaktan kaçınmak serviks kanseri taramasına katılımı azaltan etmenler arasında bulunmaktadır. ${ }^{46-48}$

Obeziteyle beraber kadınlarda görülen hiperinsülinemi, anjiyojenezi teşvik ederek meme epitel hücrelerinde östrojen ile sinerjik bir etkiye sahip 
insülin benzeri büyüme faktörü ve leptinin düzeylerini arttırır ve meme karsinogenezisini teşvik edebilmektedir. Meme kanseri olan obez kadınlarda, daha yüksek oranda kanserin tekrarlamasına, meme cerrahisinden sonra yara komplikasyonlarına ve lenfödem gibi artmış hastalık morbiditesine sahip olmaktadır. Meme kanseri tanısında obez olan kadınlarda normal kilolu kadınlara oranla kansere bağlı ve genel mortaliteyi $\% 30$ oranında arttırdığ belirtilmektedir. Ayrica, kanser teşhisi konduktan sonra total vücut ağırlığının \%10 veya daha fazlası kazanıldığında hayatta kalma oranları daha da azalmaktadır.,46

\section{SONUC}

Sağlığı olumsuz yönde etkileyecek artmış adipoz dokunun sebep olduğu obezite, herkesi etkisi altına alan önemli bir halk sağlığı problemidir. Adipoz doku salınımları, endokrin ve metabolik olarak vücudu etkilemesinin yanı sira steroid-cinsiyet hormonlarının tutulumuna da neden olmaktadır. Erkeklere oranla kadınlarda daha fazla görülen obezite, kadın sağlığı üzerinde birçok soruna yol açmaktadır. Polikistik overinfertilite, gebelik komplikasyonları, gestasyonel diabetes mellitus, anne sütü kalitesi ve bazı kanserlerin gelişimine bağlı negatif etkileri göz önüne alırsak, kadınlarda yaşam kalitesinin daha da arttırılması için ağırlık yönetiminin sağlanması çok büyük önem kazanmaktadır.

\section{KAYNAKÇA}

1. World healthy organization web sites, definition of obesity, http://www.who.int/mediacentre/factsheets/fs $311 /$ en/ October 15, 2017.

2. Türkiye İstatistik Kurumu İnternet Sitesi, Basın Odasi Haberleri, 8 Ekim 2015, http://www.tuik.gov.tr/basinOdasi/haberler/2015 58 20151008.pdf November 01, 2017.

3. Del Río JP, Alliende MI, Molina N, Serrano FG, Molina S, Vigil P. Steroid hormones and their action in women's brains: The importance of hormonal balance. Front Public Health. 2018;6: 141.

4. Kulie T, Slattengren A, Redmer J, Counts H, Eglash A, Schrager S. Obesity and women's health: An Evidence-Based Review. J Am Board Fam Med. 2011;24(1):75-85.

5. Hruby A, Hu FB. The epidemiology of obesity: A Big Picture. PharmacoEconomics. 2015;33(7): 673-689.

6. Baş M, Sağlam D. Yetişkinlerde ağırlık yönetimi. Alphan E (ed). Hastalıklarda Beslenme Tedavisi. Ankara Hatiboğlu Yayınlar1;2013:171-172.

7. Baysal A. Beslenme. 14. Bask1, Ankara:Hatiboğlu Yayınlar1;2012:535-539.

8. Vázquez-Vela MEF, Torres N, Tovar A. White adipose tissue as endocrine organ and its role in obesity. Archives of Medical Research. 2008;39(8):715-728.

9. Smitka $K$, Marešová $D$. Adipose tissue as an endocrine organ: an update on pro-inflammatory and anti-inflammatory microenvironment. Prague Medical Report. 2015;116 (2):87-111.

10. Coelho M, Oliveira T, Fernandes R. Biochemistry of adipose tissue: an endocrine organ. Arch Med Sci. 2013;9(2):191-200.

11. Cypess AM, Lehman SH, Williams G, et al. Identification and importance of brown adipose tissue in adult humans. N Engl J Med. 2009; 360:1509-1517.

12. Lanthier N, Leclercq IA. Adipose tissues as endocrine target organs, Best Practice \& Research Clinical Gastroenterology. 2014;28(4):545-558.

13. Kusminski CM, Scherer PE. Mitochondrial dysfunction in white adipose tissue, Trends Endocrinol Metab. 2012;23(9):435-443.

14. Crujeiras AB, Carreira MC, Cabia B, Andrade S, Amil M, Casanueva FF. Leptin resistance in obesity: an epigenetic landscape. Life Science. 2015;140(1):57-63.

15. Galic S, Oakhilla JS, Steinberg GR. Adipose tissue as an endocrine organ. Molecular and Cellular Endocrinology. 2010;316(2):129-139.

16. Wozniak SE, Gee LL, Wachtel MS, Frezza EE. Adipose tissue: the new endocrine organ. A Review Article. 2009;54(9):1847-1856.

17. Mankowska A, Nowak L, Sypniewska G. Adiponectin and metabolic syndrome in women at menopause. EJIFCC. 2009;19(4):173-184.

18. Cawthorn WP, Sethi JK. TNF- $\alpha$ and adipocyte biology. FEBS Lett. 2008;582(1):117-131.

19. Greenberg AS, Obin MS. Obesity and the role of adipose tissue in inflammation and metabolism. Am J Clin Nutr. 2006;83(2):461-465.

20. Dağ ZÖ, Dilbaz B. Impact of obesity on infertility in women. $J$ Türk Ger Gynecol Assoc. 2015;16(2): 111-117.

21. Sirmans SM, Pate KA. Epidemiology, diagnosis, and management of polycystic ovary syndrome. Clin Epidemiol. 2014;6:1-13.

22. Motta AB. The role of obesity in the development of polycystic ovary syndrome. Curr Pharm Des. 2012;18(17):2482-2491.

23. Messinis IE, Messini CI, Anifandis G, Dafopoulos K. Polycystic ovaries and obesity. Best Practice and Research, Clinical Obstetrics and Gynaecology. 2015;29(4):479-488.

24. McLaughlin T, Lamendola C, Liu A, Abbasi F. Preferential fat deposition in subcutaneous versus visceral depots is associated with insulin sensitivity. $J$ Clin Endocrinol Metab. 2011;96(11):1756-60.

25. Ye J. Mechanisms of insulin resistance in obesity. Front Med. 2013;7(1):14-24.

26. Segula D. Complications of obesity in adults: A short review of the literatüre. Malawi Med $\mathrm{J}$. 2014;26(1):20-24.

27. Kelly CJ, Stenton SR, Lashen H. Insulin-like growth factor binding protein-1 in PCOS: a systematic review and meta-analysis. Hum Reprod Update. 2011;17(1):4-16.

28. Vrbikova J, Hainer V. Obesity and polycystic ovary syndrome. Obes Facts. 2009;2(1):26-35.

29. Sirmans SM, Pate KA. Epidemiology, diagnosis, and management of polycystic ovary syndrome. Clin Epidemiol. 2014;6:1-13.

30. Lim SS, Norman RJ, Davies MJ, Moran LJ. The effect of obesity on polycystic ovary syndrome: a 
systematic review and meta-analysis. Obes Rev. 2013;14(2):95-109.

31. Brewer CJ, Balen AH. The adverse effects of obesity on conception and implantation. Reproduction. 2010;140:347-364.

32. Racusin D, Stevens B, Campell G, Aagaard-Tillery K. Obesity and the risk and detetion of fetal malformations. Semin Perinatol. 2012;36(3):213221.

33. Korkmaz L, Baştuğ O, Kurtoğlu S. Maternal obesity and its short- and long-term maternal and infantile effects. J Clin Res Pediatr Endocrinol. 2016;8(2):114-124.

34. National Institutes of Health web sites, Risk of Newborn Heart Defects Increases with Maternal Obesity. https://www.nih.gov/news-events/newsreleases/risk-newborn-heart-defects-increasesmaternal-obesity. Accessed November 7, 2017.

35. KC K, Shakya S, Zhang H. Gestational diabetes mellitus and macrosomia: a literature review. Ann Nutr Metab. 2015;66(2):14-20.

36. American diabetes association. gestational diabetes mellitus. Diabetes Care. 2003;26(1):103105.

37. Nagle C, Skouteris H, Morris H, et al. Primary prevention of gestational diabetes for women who are overweight and obese: a randomised controlled trial, BMC Pregnancy and Childbirth. 2013;13:65.

38. Köksal G, Gökmen H. Gestasyonel Diabetes Mellitus. Çocuk hastalıklarında beslenme tedavisi, 4. Bask1, Ankara, Hatiboğlu Yayınları; 2013:603605.

39. Heude B, Thiébaugeorges O, Goua V, et al. Prepregnancy body mass index and weight gain during pregnancy: relations with gestational diabetes and hypertension, and birth outcomes. Maternal and Child Health Journal. 2012;6(2):355-363.
40. Kahn BB, Flier JS. Obesity and insulin resistance. J Clin Invest. 2000;106(4):473-481.

41. Kim SY, Sharma AJ, Callaghana WM. Gestational diabetes and childhood obesity: what is the link. Curr Opin Obstet Gynecol. 2012;24(6):376-381.

42. Neville MC, Morton JM, Umemura SU. Lactogenesis, the transition from pregnancy to lactation. Pediatric Clinics. 2001;48(1):35-52.

43. Amir LH, Donath S. A systematic review of maternal obesity and breastfeeding intention, initiation and duration. BMC Pregnancy Childbirth. 2007;7:9.

44. Fields DA, George B, Williams $M$, et al. Associations between human breast milk hormones and adipocytokines and infant growth and body composition in the first 6 months of life. Pediatr Obes. 2017;1:78-85.

45. Pergola GD, Silvestris F. Obesity as a major risk factor for cancer. J Obes. 2013;2013:11.

46. Benedetto C, Salvagno F, Canuto EM, Gennarelli G. Obesity and female malignancies. Best Practice \& Research Clinical Obstetrics \& Gynaecology. 2015;29(4):528-540.

47. Carlson MJ, Thiel KW, Yang S, Leslie KK. Catch it before it kill: progesterone, obesity, and the prevention of endometrial cancer. Discov Med. 2012;14(76):215-222.

48. Maruthur NM, Bolen S, Brancati FL, Clark JM. The association of obesity and cervical cancer screening: a systematic review and meta-analysis. Obesity (Silver Spring). 2009;17(2):375-381. 